Cite this: Phys. Chem. Chem. Phys., 2016, 18, 11374

Received 20th January 2016, Accepted 29th March 2016

DOI: $10.1039 / c 6 c p 00437 g$

www.rsc.org/pccp

\section{Proton coupled electron transfer from the excited state of a ruthenium(II) pyridylimidazole complex $\dagger$}

\begin{abstract}
Andrea Pannwitz and Oliver S. Wenger*
Proton coupled electron transfer (PCET) from the excited state of $\left[\mathrm{Ru}(\mathrm{bpy})_{2} \mathrm{pyimH}\right]^{2+}\left(\mathrm{bpy}=2,2^{\prime}-\right.$ bipyridine; pyimH $=2-\left(2^{\prime}\right.$-pyridyl)imidazole) to $\mathrm{N}$-methyl-4,4'-bipyridinium (monoquat, $\left.\mathrm{MQ}^{+}\right)$was studied. While this complex has been investigated previously, our study is the first to show that the formal bond dissociation free energy (BDFE) of the imidazole- $\mathrm{N}-\mathrm{H}$ bond decreases from $\left(91 \pm 1 \mathrm{kcal} \mathrm{mol}^{-1}\right.$ in the electronic ground state to $(43 \pm 5) \mathrm{kcal} \mathrm{mol}^{-1}$ in the lowest-energetic ${ }^{3} \mathrm{MLCT}$ excited state. This makes the $\left[\mathrm{Ru}(\mathrm{bpy})_{2} \text { pyimH }\right]^{2+}$ complex a very strong (formal) hydrogen atom donor even when compared to metal hydride complexes, and this is interesting for light-driven (formal) hydrogen atom transfer (HAT) reactions with a variety of different substrates. Mechanistically, formal HAT between ${ }^{3} \mathrm{MLCT}$ excited $\left[\mathrm{Ru}(\mathrm{bpy})_{2} \text { pyimH }\right]^{2+}$ and monoquat in buffered $1: 1(\mathrm{v}: \mathrm{v}) \mathrm{CH}_{3} \mathrm{CN} / \mathrm{H}_{2} \mathrm{O}$ was found to occur via a sequence of reaction steps involving electron transfer from $\mathrm{Ru}(\|)$ to $\mathrm{MQ}^{+}$coupled to release of the $\mathrm{N}-\mathrm{H}$ proton to buffer base, followed by protonation of reduced $\mathrm{MQ}^{+}$by buffer acid. Our study is relevant in the larger contexts of photoredox catalysis and light-to-chemical energy conversion.
\end{abstract}

\section{Introduction}

Hydrogen atom transfer (HAT) is important in enzymes and in synthetic organic chemistry, for example for hydrogenations of unsaturated compounds such as ketones and imines. It would be attractive to use visible light to perform HAT reactions under mild reaction conditions, and therefore we explored the (formal) HAT chemistry of photoexcited $\left[\mathrm{Ru}(\mathrm{bpy})_{2} \mathrm{pyimH}\right]^{2+}$ (bpy $=2,2^{\prime}-$ bipyridine; pyimH $=2$-( $2^{\prime}$-pyridyl)imidazole). In pure HAT the transferred electron and proton originate from the same donor orbital, whereas in unidirectional proton coupled electron transfer (PCET) the transfer of a net hydrogen atom occurs from different donor orbitals. ${ }^{1-5}$ This is in fact the case for excited $\left[\mathrm{Ru}(\mathrm{bpy})_{2} \text { pyimH }\right]^{2+}$ because the metal center acts as an electron donor, whereas the proton is released from the pyimH ligand. While early PCET studies have focused largely on reactions between molecules in their electronic ground states, ${ }^{6-11}$ photoinduced PCET is now receiving increasing attention. ${ }^{1,12-25}$ Formal HAT between a transition metal complex in its ${ }^{3}$ MLCT excited-state and various reaction partners either across a salt bridge, ${ }^{14,20-23}$ or via hydrogen bonding interactions have been explored. ${ }^{13,24,25}$ Even hydride transfer from the excited state of an iridium complex was reported recently. ${ }^{26}$ In order to predict the reactivity of an excited state, thermodynamic quantities such

Department of Chemistry, University of Basel, St. Johanns-Ring 19, 4056 Basel, Switzerland. E-mail: oliver.wenger@unibas.ch

$\dagger$ Electronic supplementary information (ESI) available: additional optical spectroscopic and electro-chemical data. See DOI: $10.1039 / \mathrm{c} 6 \mathrm{cp} 00437 \mathrm{~g}$ as its redox potential and acidity constant must be known. ${ }^{27,28}$ For HAT reactions, the determination of bond dissociation free energies (BDFEs) is useful, while for PCETs the calculation of formal BDFEs has proven meaningful. ${ }^{28}$ This is possible for reactions in the ground state as well as for reactions with excited species. Based on this concept, photochemical conversions of ketones to ketyls could be rationalized. ${ }^{2,16,17}$

The $\left[\mathrm{Ru}(\mathrm{bpy})_{2} \text { pyimH }\right]^{2+}$ complex (Fig. 1) has long been known, ${ }^{29}$ in particular Haga and coworkers explored a variety of ruthenium and osmium complexes with pyimH and related (deprotonatable) ligands. ${ }^{30-35}$ Later, Gray and coworkers explored the acid-base and redox chemistry of $\left[\mathrm{Ru}(\mathrm{bpy})_{2} \mathrm{pyimH}\right]^{2+}$ and related complexes in the ground and the lowest ${ }^{3} \mathrm{MLCT}$ excited state. ${ }^{29,36}$ However, the formal BDFE of the peripheral $\mathrm{N}-\mathrm{H}$ bond of $\left[\mathrm{Ru}(\mathrm{bpy})_{2} \text { pyimH }\right]^{2+}$ and related complexes has never been determined, and the excited-state PCET chemistry remained unexplored, except in the case of an $\operatorname{Ir}(\mathrm{III})$ complex with a

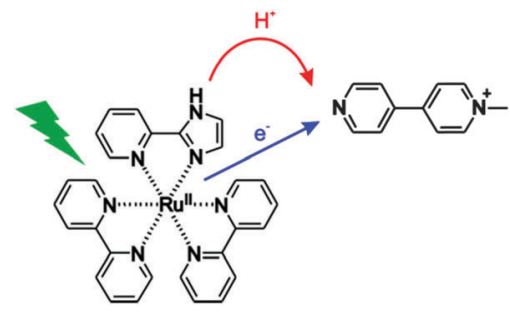

Fig. 1 The investigated process in this work: transfer of one electron and one proton from $\left[\mathrm{Ru}(\mathrm{bpy})_{2} \mathrm{pyimH}\right]^{2+}$ to monoquat $\left(\mathrm{MQ}^{+}\right)$upon photoexcitation, corresponding to net transfer of a hydrogen atom. 
2,2'-biimidazole ligand. ${ }^{14}$ In structurally related complexes such as $\left[\mathrm{Ru}(\mathrm{acac})_{2} \text { pyimH }\right]^{2+}$ (acac $=$ acetylacetonato), formal BDFEs were estimated for the electronic ground state, and values around $62 \mathrm{kcal} \mathrm{mol}^{-1}$ were found. ${ }^{9,37} \mathrm{We}$ anticipated that $\left[\mathrm{Ru}(\mathrm{bpy})_{2} \text { pyimH }\right]^{2+}$ might exhibit an unusually low $\mathrm{N}-\mathrm{H}$ BDFE in its long-lived ${ }^{3}$ MLCT excited state, making it potentially an equally potent (formal) hydrogen atom donor as previously investigated metal hydride complexes in their electronic ground states. $^{4,38}$

In the following we present the thermochemical characterization of ground and ${ }^{3} \mathrm{MLCT}$ excited states of $\left[\mathrm{Ru}(\mathrm{bpy})_{2} \text { pyimH }\right]^{2+}$ in buffered $1: 1$ (v:v) $\mathrm{CH}_{3} \mathrm{CN} / \mathrm{H}_{2} \mathrm{O}$. In this solvent mixture, welldefined $\mathrm{pH}$ values can easily be obtained by a variety of buffers and the solubility of $\left[\mathrm{Ru}(\mathrm{bpy})_{2} \mathrm{pyimH}\right]^{2+}$ as well as that of a variety of substrates is good. We find an $\mathrm{N}-\mathrm{H}$ BDFE of only $(43 \pm 5) \mathrm{kcal} \mathrm{mol}^{-1}$ in the emissive ${ }^{3}$ MLCT excited state based on thermodynamic cycles and on the photoinduced PCET chemistry with monoquat $\left(\mathrm{MQ}^{+}\right)$. The acceptor was chosen due to its ability to act as a combined electron-proton acceptor, the favourable spectroscopic properties of its radical form and the importance of pyridyl radicals for the reduction of $\mathrm{CO}_{2} \cdot{ }^{39-41}$ The PCET reaction mechanism between photoexcited $\left[\mathrm{Ru}(\mathrm{bpy})_{2} \text { pyimH }\right]^{2+}$ and $\mathrm{MQ}^{+}$was explored in detail.

\section{Results and discussion}

\section{Spectroscopy and thermodynamics of the ground state}

$\mathbf{p} K_{\mathrm{a}}$ of $\left[\mathrm{Ru}(\mathbf{b p y})_{2} \mathbf{p y i m} \mathbf{H}\right]^{2+}$. For determination of the $\mathrm{p} K_{\mathrm{a}}$ value of the electronic ground state, absorption spectra were recorded at different $\mathrm{pH}$ values between $\mathrm{pH} 3.7$ and $\mathrm{pH} 10.2$ $($ ESI, $\dagger$ Fig. S1a) using suitable buffers. By plotting the absorbance at the MLCT absorption maxima at $460 \mathrm{~nm}$ (protonated form) and $491 \mathrm{~nm}$ (deprotonated form) and sigmoidal fitting, $\mathrm{p} K_{\mathrm{a}}=8.1 \pm 0.1$ was found for $1: 1$ (v:v) $\mathrm{CH}_{3} \mathrm{CN} / \mathrm{H}_{2} \mathrm{O}$ (ESI, $\dagger$ Fig. S1b), in agreement with a prior study that reported $\mathrm{p} K_{\mathrm{a}}=7.9 \pm 0.1$ in $\mathrm{H}_{2} \mathrm{O}$ containing $5 \%$ methanol. $^{29}$

$\mathbf{p} K_{\mathbf{a}}$ of $\left[\mathrm{Ru}(\mathrm{bpy})_{2} \mathrm{pyimH}\right]^{3+}$. Oxidative cyclic voltammetry sweeps probing metal oxidation were performed in the $\mathrm{pH}$ range between $\mathrm{pH} 1$ and $\mathrm{pH}$ 11. Characteristic voltammograms for three $\mathrm{pH}$ regions of interest are shown in Fig. 2a. In the acidic $\mathrm{pH}$ range where $\left[\mathrm{Ru}(\mathrm{bpy})_{2} \mathrm{pyimH}\right]^{2+}$ remains protonated after oxidation of $\mathrm{Ru}^{\mathrm{II}}$ to $\mathrm{Ru}^{\mathrm{III}}$, the voltammograms show one reversible oxidation wave at $E_{\mathrm{ox}}^{\text {prot }}=(1.00 \pm 0.05) \mathrm{V} v s$. SCE with peak separations between 67 and $80 \mathrm{mV}$. This behaviour is observed up to $\mathrm{pH}=3.6 \pm 0.1$, corresponding to the acidity constant of $\left[\mathrm{Ru}(\mathrm{bpy})_{2} \mathrm{pyimH}\right]^{3+}\left(\mathrm{p} K_{\mathrm{a}}^{\mathrm{ox}}\right)$. At higher $\mathrm{pH}$ values oxidation is irreversible at a sweep rate of $100 \mathrm{mV} \mathrm{s}^{-1}$ (Fig. 2a and Fig. S5 in the ESI $\dagger$ ) due to deprotonation of the pyimH ligand of the

Table 1 Acidity constants of $\left[\mathrm{Ru}(\mathrm{bpy})_{2} \text { pyimH }\right]^{2+}$ in $1: 1(\mathrm{v}: \mathrm{v}) \mathrm{CH}_{3} \mathrm{CN} / \mathrm{H}_{2} \mathrm{O}$ in the electronic ground state $\left(\mathrm{p} K_{\mathrm{a}}\right)$, in the long-lived ${ }^{3} \mathrm{MLCT}$ excited state $\left(\mathrm{p} K_{\mathrm{a}}{ }^{*}\right)$ and in the one-electron oxidized form $\left(\mathrm{p} K_{\mathrm{a}}^{\mathrm{ox}}\right)$

$\begin{array}{ll}\mathrm{p} K_{\mathrm{a}} & 8.1 \pm 0.1 \\ \mathrm{p} K_{\mathrm{a}}^{*} & 5.6 \pm 0.3 \\ \mathrm{p} K_{\mathrm{a}}^{\mathrm{ox}} & 3.6 \pm 0.1\end{array}$
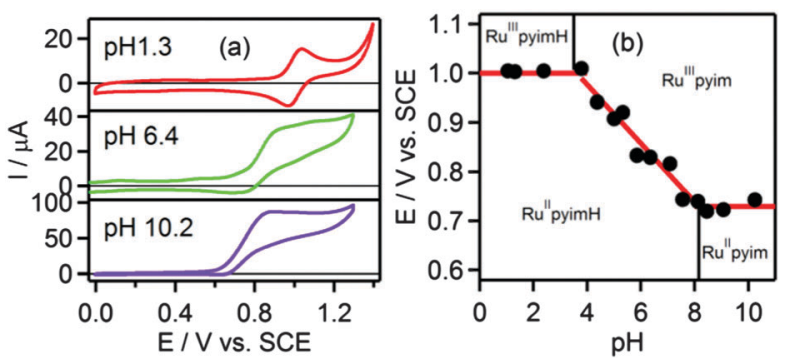

Fig. 2 (a) Voltammograms of $\left[\mathrm{Ru}(\mathrm{bpy})_{2} \text { pyimH }\right]^{2+}$ in $1: 1$ (v: v) $\mathrm{CH}_{3} \mathrm{CN} / \mathrm{H}_{2} \mathrm{O}$ with $0.05 \mathrm{M}$ buffer at different $\mathrm{pH}$ values, (b) Pourbaix diagram of $\left[\mathrm{Ru}(\mathrm{bpy})_{2} \mathrm{pyimH}\right]^{2+}$. The slope between $\mathrm{pH} 3.6$ and $\mathrm{pH} 8.1$ is $-(60 \pm 4) \mathrm{mV}$ per $\mathrm{pH}$. A comprehensive set of voltammograms is shown in Fig. S5 of the ESI. $\dagger$

Table 2 Ground and excited state redox potentials $\left(E_{\text {ox }},{ }^{*} E_{\text {ox }}\right),{ }^{3} \mathrm{MLCT}$ energy $\left(E_{0-0}\right)$, emission maxima at $25^{\circ} \mathrm{C}\left(\lambda_{\max }\right)$ and luminescence lifetimes at $25{ }^{\circ} \mathrm{C}$ under aerated and deaerated conditions of $\left[\mathrm{Ru}(\mathrm{bpy})_{2} \text { pyimH }\right]^{2+}$ in $1: 1$ (v: v) $\mathrm{CH}_{3} \mathrm{CN} / \mathrm{H}_{2} \mathrm{O}$ with $0.05 \mathrm{M}$ buffer

\begin{tabular}{|c|c|c|}
\hline & {$\left[\mathrm{Ru}(\mathrm{bpy})_{2} \text { pyimH }\right]^{2+}$} & {$\left[\mathrm{Ru}(\mathrm{bpy})_{2} \text { pyim }\right]^{+}$} \\
\hline$E_{\mathrm{Ox}}[\mathrm{V} v s . \mathrm{SCE}]$ & $1.00 \pm 0.05$ & $0.73 \pm 0.05$ \\
\hline${ }^{*} E_{\mathrm{Ox}}[\mathrm{V} v s . \mathrm{SCE}]$ & $-1.1 \pm 0.1$ & $-1.2 \pm 0.1$ \\
\hline$E_{0-0}[\mathrm{eV}]$ & $2.1 \pm 0.1^{a, b}$ & $1.9 \pm 0.1^{b}$ \\
\hline$\lambda_{\max }[\mathrm{nm}] 25{ }^{\circ} \mathrm{C}$ & $625 \pm 5$ & $675 \pm 5$ \\
\hline$\tau[\mathrm{ns}]$ aerated & $110 \pm 10$ & $50 \pm 5$ \\
\hline$\tau[\mathrm{ns}]$ deaerated & $210 \pm 20$ & $70 \pm 7$ \\
\hline
\end{tabular}

oxidized complex. Oxidation potentials of the deprotonated complex were estimated by determining the relevant inflection points of the oxidation waves. Plotting the oxidation potentials in volt $v s$. $\mathrm{pH}$ gives the data points for the Pourbaix diagram in Fig. $2 b$. In the range between $\mathrm{p} K_{\mathrm{a}}^{\mathrm{ox}}=3.6$ and $\mathrm{p} K_{\mathrm{a}}=8.1$ the $\mathrm{Ru}^{\mathrm{II} / \mathrm{III}}$ oxidation wave shifts cathodically with a slope of $-(60 \pm 4) \mathrm{mV}$ per $\mathrm{pH}$ unit, as expected for a 1-electron-1-proton-process. Oxidation of the deprotonated complex, $\left[\mathrm{Ru}(\mathrm{bpy})_{2} \text { pyim }\right]^{+}$, occurs at $E_{\mathrm{Ox}}^{\mathrm{dep}}=(0.73 \pm 0.05) \mathrm{V} v s$. SCE (Table 2$)$. Thus, the total cathodic shift between oxidation potentials of $\left[\mathrm{Ru}(\mathrm{bpy})_{2} \text { pyimH }\right]^{2+}$ and $\left[\mathrm{Ru}(\mathrm{bpy})_{2} \text { pyim }\right]^{+}$is $270 \mathrm{mV}$, which is smaller than the previously reported shift of $380 \mathrm{mV}$ in neat acetonitrile. ${ }^{29}$

\section{Excited state properties}

Excited state $\mathbf{p} \boldsymbol{K}_{\mathrm{a}}{ }^{*}$ of $\left[\mathrm{Ru}(\mathrm{bpy})_{2} \mathrm{pyimH}\right]^{2+}$. Luminescence spectra of $\left[\mathrm{Ru}(\mathrm{bpy})_{2} \text { pyimH }\right]^{2+}$ were measured between $\mathrm{pH} 3$ and $\mathrm{pH} 10$ in $1: 1(\mathrm{v}: \mathrm{v}) \mathrm{CH}_{3} \mathrm{CN} / \mathrm{H}_{2} \mathrm{O}$ containing $0.05 \mathrm{M}$ buffer to control the $\mathrm{pH}$ (Fig. 3a). All spectra were recorded at identical complex concentration and their intensity was normalized to the intensity of the most acidic sample; excitation occurred into the isosbestic point at $474 \mathrm{~nm}$ (Fig. S1a, ESI $\dagger$ ). The decrease in intensity is due to different luminescence quantum yields of the protonated and deprotonated complex and due to deprotonation in the excited state. Emission decays were measured at $630 \mathrm{~nm}$ to determine the lifetimes of the protonated $\left(\tau^{\text {prot }}\right)$ and deprotonated ${ }^{3}$ MLCT state $\left(\tau^{\text {dep }}\right)$ in aerated and deaerated solution (Table 2). For these measurements the complex was excited at $532 \mathrm{~nm}$ with laser pulses of $c a .10 \mathrm{~ns}$ duration. 

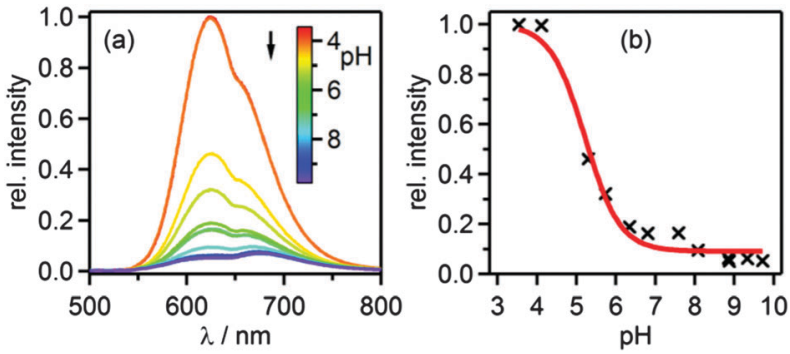

Fig. 3 (a) Luminescence of $40 \mu \mathrm{M}\left[\mathrm{Ru}(\mathrm{bpy})_{2} \text { pyimH }\right]^{2+}$ in aerated 1:1(v:v) $\mathrm{CH}_{3} \mathrm{CN} / \mathrm{H}_{2} \mathrm{O}$ with $0.05 \mathrm{M}$ buffer at different $\mathrm{pH}$ values following excitation into the isosbestic point at $474 \mathrm{~nm}$. (b) Relative luminescence intensity at $625 \mathrm{~nm}$ vs. $\mathrm{pH}$.

The acidity constant in the long-lived ${ }^{3}$ MLCT-state $\left(\mathrm{pK}_{\mathrm{a}}{ }^{*}\right)$ was then determined from the inflection point of the steady-state emission titration curve $\left(\mathrm{pH}_{\mathrm{i}}=5.2 \pm 0.2\right)$ in Fig. $3 \mathrm{~b}$ and the excited-state lifetimes of protonated $\left(\tau^{\mathrm{prot}}\right)$ and deprotonated complex $\left(\tau^{\text {dep }}\right)$.

$$
\mathrm{p} K_{\mathrm{a}}^{*}=\mathrm{pH}_{\mathrm{i}}+\log \left[\tau^{\mathrm{prot}} / \tau^{\mathrm{dep}}\right]
$$

With eqn (1) one obtains $\mathrm{p}_{\mathrm{a}}{ }^{*}=5.6 \pm 0.3 .{ }^{27}$ Based on the emission maxima of $\left[\mathrm{Ru}(\mathrm{bpy})_{2}(\text { pyimH })\right]^{2+}$ and $\left[\mathrm{Ru}(\mathrm{bpy})_{2}(\text { pyim })\right]^{+}$at $25{ }^{\circ} \mathrm{C}$, the Förster equation yields $\mathrm{p} K_{\mathrm{a}}{ }^{*}=5.3 \pm 0.6$ (ESI, $\dagger$ page S6). This value is in good agreement with that determined from the luminescence titration, and also with the previously reported $\mathrm{p} K_{\mathrm{a}}{ }^{*}$ in water with $5 \%$ methanol. ${ }^{29}$ The increase of acidity in the excited state compared to the ground state indicates that the ${ }^{3}$ MLCT state is localized on the bpy spectator ligands, as noted earlier. ${ }^{36}$

Transient absorption spectra were measured using pulsed laser excitation at $532 \mathrm{~nm}$. Under acidic conditions (Fig. 4a), $\left[\mathrm{Ru}(\mathrm{bpy})_{3}\right]^{2+}$-like transient spectra were observed, exhibiting a bleach around $450 \mathrm{~nm}$ and increased intensity around $370 \mathrm{~nm} .{ }^{43}$ At basic $\mathrm{pH}$ the MLCT band is red-shifted (ESI, $\uparrow$ Fig. S1), and therefore the MLCT-bleach in transient absorption is red-shifted as well (Fig. 4b). Transients that were recorded in the $\mathrm{pH}$ range between $\mathrm{pH} 5.0$ and 8.1 exhibit a prominent feature at $500 \mathrm{~nm}$ (Fig. 4c) which can be explained by deprotonation in the excited state and the accumulation of deprotonated complex in the ground state. This interpretation is confirmed by a subtraction of the ground-state UV-vis spectra of the protonated and deprotonated complex (Fig. 4d) which also exhibits the prominent positive feature at $500 \mathrm{~nm}$. The temporal evolution of this signal at pH 6.4 in presence of $0.05 \mathrm{M}$ acetic acid/sodium acetate buffer and $c a \cdot 10^{-5} \mathrm{M}$ complex concentration is shown below. In the absence of any reaction partner the formation of $\left[\mathrm{Ru}(\mathrm{bpy})_{2} \text { pyim }\right]^{+}$, the deprotonated complex in its ground state, occurs with a time constant of $\tau=(60 \pm 10)$ ns. Re-protonation then occurs with a time constant of $\tau=(106 \pm 10)$ ns as discussed later. The kinetics of these deprotonation and protonation events are dictated by the buffer concentration. At $\mathrm{pH} 6.3$ the quenching constant $k_{\mathrm{q}}$ is $(8.3 \pm 0.5) \times 10^{8} \mathrm{~L} \mathrm{~mol}^{-1} \mathrm{~s}^{-1}$ based on a Stern-Volmer luminescence quenching experiment (ESI, $\dagger$ Fig. S7).

At any given $\mathrm{pH}$ and buffer concentration, the amount of accumulated $\left[\mathrm{Ru}(\mathrm{bpy})_{2} \mathrm{pyim}\right]^{+}$in the ground state correlates

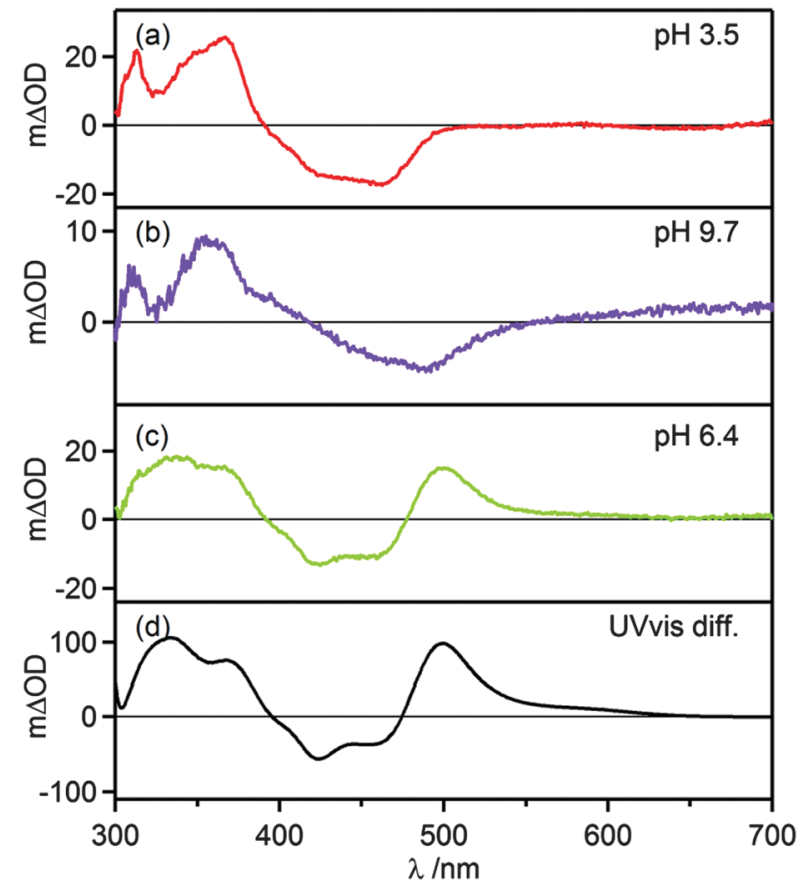

Fig. $4(\mathrm{a}-\mathrm{c})$ Transient absorption spectra of $20 \mu \mathrm{M}\left[\mathrm{Ru}(\mathrm{bpy})_{2} \text { pyimH }\right]^{2+}$ in $1: 1$ (v: v) $\mathrm{CH}_{3} \mathrm{CN} / \mathrm{H}_{2} \mathrm{O}$ with $0.05 \mathrm{M}$ buffer at different $\mathrm{pH}$ values. Excitation occurred at $532 \mathrm{~nm}$ with laser pulses of ca. $10 \mathrm{~ns}$ duration, the spectra were recorded without time delay over a period of $200 \mathrm{~ns}$. (d) Difference of ground state UV-vis spectra of protonated and deprotonated complex.

with the acid-base equilibration in the ${ }^{3}$ MLCT excited state, and this reflects directly in the intensity of the transient band at $500 \mathrm{~nm}$. A plot of the change in optical density at $500 \mathrm{~nm} v s . \mathrm{pH}$ yields an inflection point at pH $5.6 \pm 0.2$ (ESI, $\dagger$ Fig. S4), in line with the $\mathrm{p} K_{\mathrm{a}}{ }^{*}$ value determined by luminescence titration and the Förster equation.

Thus, at sufficiently high $\mathrm{pH},\left[\mathrm{Ru}(\mathrm{bpy})_{2} \text { pyimH }\right]^{2+}$ exhibits ordinary photoacid behavior similar to hydroxyarenes such as naphthols and hydroxypyrenetrisulfonate ("pyranine"). ${ }^{44}$

Excited state redox chemistry of $\left[\mathrm{Ru}(\mathrm{bpy})_{2} \mathrm{pyimH}\right]^{2+}$. The excited state oxidation potentials $\left({ }^{*} E_{\mathrm{ox}}\right)$ were estimated based on the ground state redox potentials $\left(E_{\text {ox }}\right)$ and the ${ }^{3}$ MLCT energy $\left(E_{0-0}\right)$ using eqn $(2){ }^{42}$

$$
{ }^{*} E_{\mathrm{Ox}}=E_{\mathrm{Ox}}-E_{0-0}
$$

$E_{0-0}$ was determined from low-temperature luminescence spectroscopy (Fig. S2, ESI $\dagger$ ). For $\left[\mathrm{Ru}(\mathrm{bpy})_{2} \text { pyimH }\right]^{2+}$ we determined $E_{0-0}^{\text {prot }}=(2.1 \pm 0.1) \mathrm{eV}^{29,42}$ and for $\left[\mathrm{Ru}(\mathrm{bpy})_{2} \text { pyim }\right]^{+}$we found $E_{0-0}^{\mathrm{dep}}=(1.9 \pm 0.1) \mathrm{eV}$. Based on these $E_{0-0}$ values (see also Table 2), excited state redox potentials of ${ }^{*} E^{\text {prot }}=-(1.1 \pm 0.1) \mathrm{V}$ $v s$. SCE and ${ }^{*} E^{\text {dep }}=-(1.2 \pm 0.1) \mathrm{V} v s$. SCE were estimated for the protonated and deprotonated complex, respectively. Expectedly, oxidation is far easier in the ${ }^{3}$ MLCT excited state than in the electronic ground state.

\section{BDFEs and "cube" scheme}

A graphical summary of all relevant thermodynamic parameters for $\left[\mathrm{Ru}(\mathrm{bpy})_{2} \text { pyimH }\right]^{2+}$ is provided in Scheme 1 . This so-called 
"cube" scheme is a three dimensional illustration displaying ground state redox potentials (blue) and acidity constants (red) on the bottom and excited state potentials (blue) and $\mathrm{p} K_{\mathrm{a}}$ values (red) on the top. ${ }^{3}$ MLCT excitation energies are represented by vertical black arrows. $\mathrm{N}-\mathrm{H}$ bond dissociation free energies (BDFEs) can be estimated using eqn (3) and the experimentally determined acidity constants and oxidation potentials. ${ }^{2,45,46}$

$$
\operatorname{BDFE}(\mathrm{N}-\mathrm{H})=1.37 \mathrm{p} K_{\mathrm{a}}+23.06 E^{\circ}+57.6 \mathrm{kcal} \mathrm{mol}^{-1}
$$

In eqn (3), $E^{\circ}$ must be entered in units of $\mathrm{V} v s$. NHE; the last summand is a solvent-characteristic parameter describing solvation of hydrogen atoms. The resulting BDFEs for $\left[\mathrm{Ru}(\mathrm{bpy})_{2} \text { pyimH }\right]^{2+}$ in the electronic ground and excited states are BDFE = $(91 \pm 1) \mathrm{kcal} \mathrm{mol}^{-1}$ and ${ }^{*} \mathrm{BDFE}=(43 \pm 5) \mathrm{kcal} \mathrm{mol}^{-1}$ (green arrows in Scheme 1). The ground-state BDFE is comparable to primary and secondary amines ${ }^{2,47,48}$ but somewhat higher than related ruthenium pyridylimidazole complexes which were characterized in acetonitrile. ${ }^{9,37}$ Upon photoexcitation, the BDFE drops by $48 \mathrm{kcal} \mathrm{mol}^{-1}$, which is essentially equal to the energy of the absorbed visible photon. Interestingly, the resulting excitedstate BDFE is comparable to metal hydride catalysts for hydrogenation reactions for which $\mathrm{M}-\mathrm{H}$ BDFEs ranging from 50 to $55 \mathrm{kcal} \mathrm{mol}^{-1}$ for $\mathrm{M}=$ vanadium, $58 \mathrm{kcal} \mathrm{mol}^{-1}$ for $\mathrm{M}=$ chromium, and $68 \mathrm{kcal} \mathrm{mol}{ }^{-1}$ for $\mathrm{M}=$ tungsten have been reported. ${ }^{4,38}$ In principle this drop in BDFE is expected to occur for other related metal complexes in the course of photoexcitation, but prior studies have not explicitly reported on this effect. Presumably this is due to the fact that in many cases the necessary redox potentials and acidity constants were not always determined in the same solvent, which complicates the application of eqn (3). Estimations based on prior work yields for the first $\mathrm{N}-\mathrm{H}$ BDFE of $\left[\mathrm{Ru}(\mathrm{bpy})_{2}\left(2,2^{\prime}\right.\right.$ biimidazole) $]^{2+}$ a decrease from 86 to $40 \mathrm{kcal} \mathrm{mol}^{-1}$ between the electronic ground state and the long-lived ${ }^{3}$ MLCT state. ${ }^{29,49}$

In order to test whether the $\mathrm{N}-\mathrm{H}$ BDFE is really that low, we set out to react photoexcited $\left[\mathrm{Ru}(\mathrm{bpy})_{2} \text { pyimH }\right]^{2+}$ in PCET

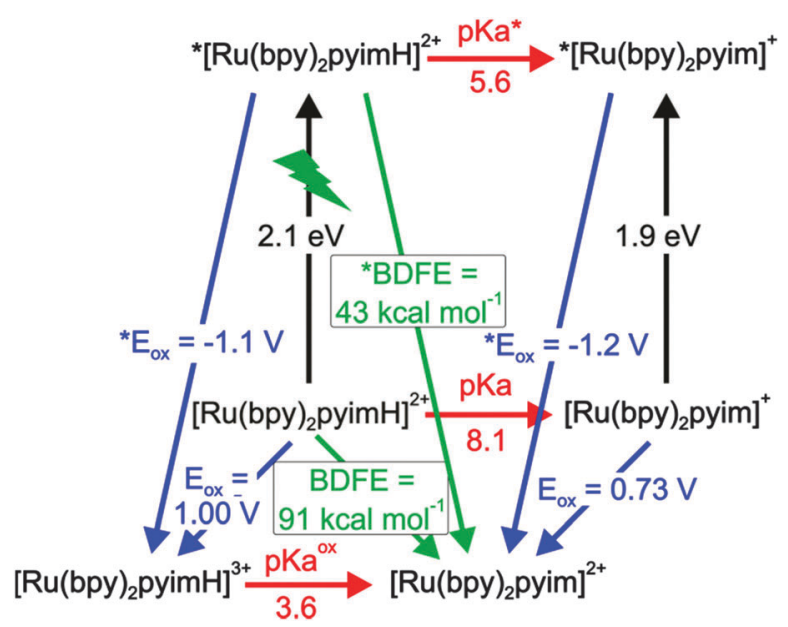

Scheme 1 Thermodynamic "cube" scheme for $\left[\mathrm{Ru}(\mathrm{bpy})_{2} \text { pyimH }\right]^{2+}$ in 1:1 (v: v) $\mathrm{CH}_{3} \mathrm{CN} / \mathrm{H}_{2} \mathrm{O}$ based on the data in Tables 1 and 2. Horizontal/red: $\mathrm{p} K_{\mathrm{a}}$ values, orthogonal in black: triplet energy $E_{0-0}$, pointing towards the reader in blue: oxidation potentials in $\mathrm{V} v$ s. SCE, diagonal in green: BDFEs.

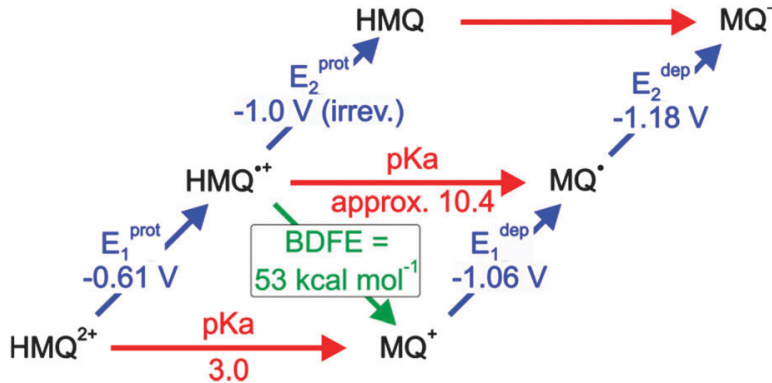

Scheme 2 Thermodynamic "square" scheme of monoquat $\left(\mathrm{MQ}^{+}\right)$in $1: 1$ (v:v) $\mathrm{CH}_{3} \mathrm{CN} / \mathrm{H}_{2} \mathrm{O}$. Horizontal with red arrows: $\mathrm{p} K_{\mathrm{a}}$ values, upward right with blue arrows: redox potentials in $\mathrm{V} v \mathrm{~S}$. SCE, downward left with green arrow: BDFEs. The $\mathrm{pK}_{\mathrm{a}}$ of $\mathrm{HMQ}^{\bullet+}$ was taken from the literature. ${ }^{46}$

chemistry with a suitable formal $\mathrm{H}$ atom acceptor. We identified $N$-methyl-4,4'-bipyridinium (monoquat, $\mathrm{MQ}^{+}$) as a promising candidate. Meyer and coworkers already proposed the use of $\mathrm{MQ}^{+}$for detecting PCET photoproducts because its one-electron reduced and protonated congener $\left(\mathrm{MQH}^{\bullet+}\right)$ exhibits absorption features that can be identified unambiguously. ${ }^{50}$

Before performing actual photochemical experiments between $\left[\mathrm{Ru}(\mathrm{bpy})_{2} \text { pyimH }\right]^{2+}$ and $\mathrm{MQ}^{+}$, the thermodynamic properties of $\mathrm{MQ}^{+}$in $1: 1(\mathrm{v}: \mathrm{v}) \mathrm{CH}_{3} \mathrm{CN} / \mathrm{H}_{2} \mathrm{O}$ were determined. The results from acid-base titration and electrochemical experiments are in the ESI $\dagger$ (Fig. S8 and S9). Here we merely report the final results in a thermodynamic "square" scheme (Scheme 2).

The key finding is that the $\mathrm{HMQ}^{\bullet+}$ radical has an N-H BDFE of $(53 \pm 1) \mathrm{kcal} \mathrm{mol}^{-1}$. Consequently, photoexcitation of $\left[\mathrm{Ru}(\mathrm{bpy})_{2} \text { pyim }\right]^{2+}$ in presence of $\mathrm{MQ}^{+}$is expected to lead to formal HAT, resulting in $\left[\mathrm{Ru}(\mathrm{bpy})_{2} \mathrm{pyim}^{+}\right.$and $\mathrm{HMQ}^{\bullet+}$. Based on an $\mathrm{N}-\mathrm{H}{ }^{*} \mathrm{BDFE}$ of $(43 \pm 5) \mathrm{kcal} \mathrm{mol}^{-1}$ for the photoexcited complex (Scheme 1), the driving-force for this reaction should be $-(10 \pm 6) \mathrm{kcal} \mathrm{mol}^{-1}$, which corresponds to $-(0.4 \pm 0.3) \mathrm{eV}$. In the following we report on the photochemistry between $\left[\mathrm{Ru}(\mathrm{bpy})_{2} \mathrm{pyimH}\right]^{2+}$ and $\mathrm{MQ}^{+}$as a function of $\mathrm{pH}$.

\section{From simple photoinduced ET to formal HAT}

In the electronic ground state, electron transfer (ET) and proton transfer reactions (PT) between $\left[\mathrm{Ru}(\mathrm{bpy})_{2} \mathrm{pyimH}\right]^{2+}$ and $\mathrm{MQ}^{+}$ are strongly endergonic $\left(\Delta G_{\mathrm{ET}}=+(2.1 \pm 0.1) \mathrm{eV}, \Delta G_{\mathrm{PT}}=\right.$ $+(0.30 \pm 0.02) \mathrm{eV})$ and therefore no ground-state chemistry occurs. Regarding excited-state chemistry, there are in fact three different $\mathrm{pH}$ domains which are discussed individually in the following 3 sub-sections.

Acidic pH - photoinduced electron transfer. In the acidic range, both the complex and the acceptor are protonated in the ground and excited state. Under these conditions, the expected reaction is photoinduced electron transfer (eqn (4)).

$$
\begin{gathered}
{ }^{*}\left[\mathrm{Ru}(\mathrm{bpy})_{2} \text { pyimH }\right]^{2+}+\mathrm{HMQ}^{2+} \rightarrow\left[\mathrm{Ru}(\mathrm{bpy})_{2} \mathrm{pyimH}^{3+}+\mathrm{HMQ}^{\bullet+}\right. \\
\Delta G_{\mathrm{ET}}=-(0.5 \pm 0.2) \mathrm{eV}
\end{gathered}
$$

The transient absorption spectrum recorded at $\mathrm{pH}=2$ (Fig. 5a) confirms this expectation. Directly after the laser pulse one observes a bleach around $450 \mathrm{~nm}$ which is compatible with 


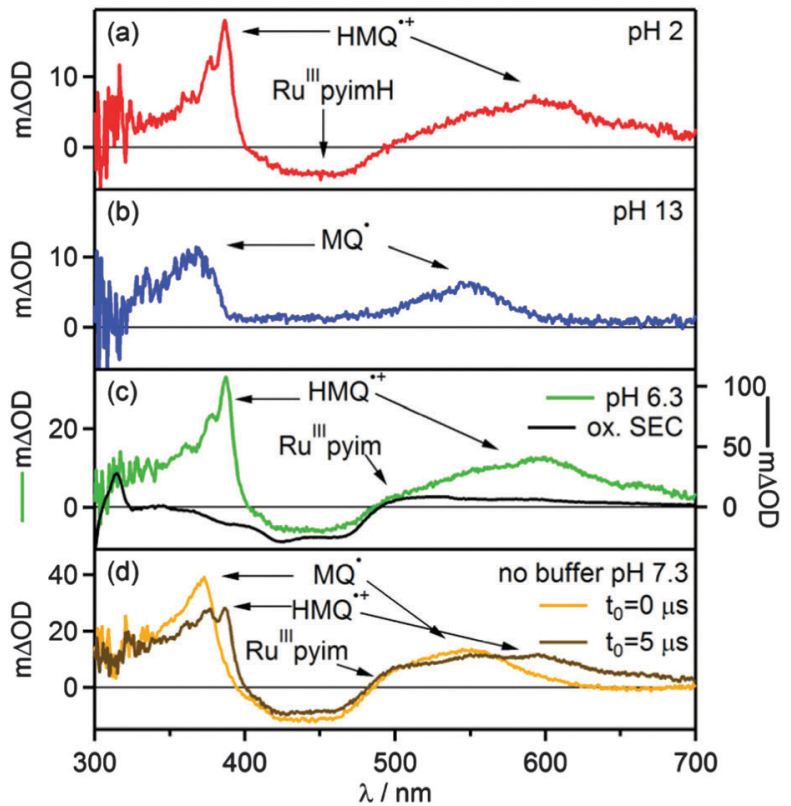

Fig. 5 Transient absorption spectra of $\left[\mathrm{Ru}(\mathrm{bpy})_{2} \text { pyimH }\right]^{2+}$ in $1: 1$ ( $\left.\mathrm{v}: \mathrm{v}\right)$ $\mathrm{CH}_{3} \mathrm{CN} / \mathrm{H}_{2} \mathrm{O}$ recorded in presence of $60 \mathrm{mM} \mathrm{MQ}{ }^{+}$following excitation at $532 \mathrm{~nm}$ with laser pulses of ca. $10 \mathrm{~ns}$ duration. Detection occurred by integration over $200 \mathrm{~ns}$. (a) $30 \mu \mathrm{M}\left[\mathrm{Ru}(\mathrm{bpy})_{2} \mathrm{pyimH}\right]^{2+}$ at $\mathrm{pH} 2$ with $0.05 \mathrm{M}$ buffer, data recorded with a delay time $\left(t_{0}\right)$ of $5 \mu \mathrm{s}$, (b) $30 \mu \mathrm{M}\left[\mathrm{Ru}(\mathrm{bpy})_{2} \mathrm{pyimH}\right]^{2+}$ at $\mathrm{pH}$ 13, data recorded with a delay time $\left(t_{0}\right)$ of $5 \mu \mathrm{s}$, (c) $50 \mu \mathrm{M}$ $\left[\mathrm{Ru}(\mathrm{bpy})_{2} \mathrm{pyimH}\right]^{2+}$ at $\mathrm{pH} 6.3$ with $0.05 \mathrm{M}$ acetate buffer, data recorded with a delay time $\left(t_{0}\right)$ of $1 \mu \mathrm{s}$. (d) $50 \mu \mathrm{M}\left[\mathrm{Ru}(\mathrm{bpy})_{2} \mathrm{pyimH}\right]^{2+}$ in unbuffered in $1: 1$ (v:v) $\mathrm{CH}_{3} \mathrm{CN} / \mathrm{H}_{2} \mathrm{O}$ at $\mathrm{pH} 7.3$ recorded without delay time (orange trace) and with a time delay of $5 \mu$ s (brown trace).

metal oxidation, and the signatures of the $\mathrm{HMQ}^{\bullet+}$ cation radical appear at $387 \mathrm{~nm}$ and $610 \mathrm{~nm}^{46}$ The latter closely resemble the well-known radical of methyl viologen $\left(\mathrm{MV}^{2+}\right){ }^{51}$ The photoinduced ET reaction from eqn (4) is associated with $\Delta G_{\mathrm{ET}}=-(0.5 \pm 0.2) \mathrm{eV}$. A Stern-Volmer experiment under acidic conditions reveals a quenching constant of $k_{\mathrm{q}}=(6.8 \pm 0.1) \times 10^{8} \mathrm{~L} \mathrm{~mol}^{-1} \mathrm{~s}^{-1}$ (ESI, $\dagger$ Fig. S14), which is comparable to what was found for the reaction of * $\left[\mathrm{Ru}(\mathrm{bpy})_{3}\right]^{2+}$ with $\mathrm{MV}^{2+}$ in water $\left(k_{\mathrm{q}}=5.9 \times 10^{8} \mathrm{~L} \mathrm{~mol}^{-1} \mathrm{~s}^{-1}\right) \cdot{ }^{52,53}$ The thermal reverse ET from $\mathrm{HMQ}^{\circ+}$ to $\left[\mathrm{Ru}(\mathrm{bpy})_{2} \text { pyimH }\right]^{3+}$ in the electronic ground state then occurs on a time scale of approximately $100 \mu \mathrm{s}$, as determined by monitoring the $\mathrm{HMQ}^{\bullet+}$ signal at $610 \mathrm{~nm}$ (ESI, $\dagger$ Fig. S10).

Basic pH - ET. In the basic range, the complex and the acceptor are both deprotonated in the ground and excited state, and consequently they are expected to undergo photoinduced electron transfer according to eqn (5).

$$
\begin{gathered}
*\left[\mathrm{Ru}(\mathrm{bpy})_{2} \text { pyim }\right]^{+}+\mathrm{MQ}^{+} \rightarrow\left[\mathrm{Ru}(\text { bpy })_{2} \text { pyim }\right]^{2+}+\mathrm{MQ}^{\bullet} \\
\Delta G_{\mathrm{ET}}=-(0.14 \pm 0.15) \mathrm{eV}
\end{gathered}
$$

In transient absorption spectroscopy, the neutral monoquat radical (MQ•) with characteristic absorptions at $365 \mathrm{~nm}$ and $545 \mathrm{~nm}$ is observed. ${ }^{51}$ The expected MLCT bleach of the ruthenium complex overlaps with a positive contribution of $\mathrm{MQ}^{\bullet}$ hence the flat region in the spectrum between 390 and $480 \mathrm{~nm}$.
The Stern-Volmer luminescence quenching experiment yields a quenching constant of $k_{\mathrm{q}}=(20.7 \pm 0.3) \times 10^{8} \mathrm{~L} \mathrm{~mol}^{-1} \mathrm{~s}^{-1}$ (ESI, $\dagger$ Fig. S15), which is close to the diffusion limit. The thermal reverse ET from $\mathrm{MQ}^{\bullet}$ to $\left[\mathrm{Ru}(\mathrm{bpy})_{2} \text { pyim }\right]^{2+}$ takes place on a time scale of $10 \mu \mathrm{s}$ (ESI, $\dagger$ Fig. S11).

Middle $\mathbf{p H}$ range - formal HAT. In the middle $\mathrm{pH}$ range the most interesting photochemistry is expected. At pH 6.3 the complex is protonated in its ground state but becomes deprotonated upon excitation to the ${ }^{3}$ MLCT state as well as upon oxidation of $\mathrm{Ru}^{\mathrm{II}}$ to $\mathrm{Ru}^{\mathrm{III}}$ (Scheme 1). On the other hand, $\mathrm{MQ}^{+}$ is not protonated, but it is expected to be protonated upon oneelectron reduction (Scheme 2). According to the formal $\mathrm{N}-\mathrm{H}$ BDFEs determined above for photoexcited $\left[\mathrm{Ru}(\mathrm{bpy})_{2} \text { pyimH }\right]^{2+}$ $\left((43 \pm 5) \mathrm{kcal} \mathrm{mol}^{-1}\right.$, Scheme 1) and for $\mathrm{HMQ}^{\bullet+}\left((53 \pm 1) \mathrm{kcal} \mathrm{mol}^{-1}\right.$, Scheme 2) the formal hydrogen atom transfer reaction in eqn (6) should be associated with a reaction free energy of $-(10 \pm 6) \mathrm{kcal} \mathrm{mol}^{-1}$.

$$
\begin{gathered}
*\left[\mathrm{Ru}^{\mathrm{II}}(\text { bpy })_{2} \text { pyimH }\right]^{2+}+\mathrm{MQ}^{+} \rightarrow\left[\mathrm{Ru}^{\mathrm{III}}(\text { bpy })_{2} \mathrm{pyim}^{2+}+\mathrm{HMQ}^{\bullet+}\right. \\
\Delta G_{\mathrm{HAT}}=-(0.44 \pm 0.16) \mathrm{eV}
\end{gathered}
$$

In transient absorption spectroscopy the two photoproducts from eqn (6) are indeed observed (Fig. 5c). When recording transient absorption spectra with a time delay $\left(t_{0}\right)$ of $1 \mu$ s there is clear evidence for $\mathrm{HMQ}^{\bullet+}$ (signals at 387 and $610 \mathrm{~nm}$ ) and for $\left[\mathrm{Ru}^{\mathrm{III}}(\mathrm{bpy})_{2} \mathrm{pyim}\right]^{2+}$ (bleach around $450 \mathrm{~nm}$ ), as confirmed by spectro-electrochemical (SEC) studies (black trace in Fig. 5c). However, mechanistically direct HAT between ${ }^{*}\left[\mathrm{Ru}^{\mathrm{II}}(\mathrm{bpy})_{2} \text { pyimH }\right]^{2+}$ and $\mathrm{MQ}^{+}$in presence of aqueous buffer is highly improbable, particularly in view of the positive charges on both reactants. Moreover, the lowest-energetic MLCT excitation in $\left[\mathrm{Ru}^{\mathrm{II}}(\mathrm{bpy})_{2} \text { pyimH }\right]^{2+}$ involves promotion of an electron into a bpy-localized orbital rather than a pyimH orbital (see above). ${ }^{36}$ Consequently, formal HAT between photoexcited $\left[\mathrm{Ru}^{\mathrm{II}}(\mathrm{bpy})_{2} \text { pyimH }\right]^{2+}$ and $\mathrm{MQ}^{+}$most likely involves a sequence of electron and proton transfer steps as illustrated in Scheme 3: following excitation of $\left[\mathrm{Ru}^{\mathrm{II}}(\mathrm{bpy})_{2} \mathrm{pyimH}\right]^{2+}$, photoinduced electron transfer to $\mathrm{MQ}^{+}$is coupled to release of the pyimH $\mathrm{N}-\mathrm{H}$ proton to buffer base (acetate anion $\left(\mathrm{AcO}^{-}\right),{ }^{*} \mathrm{PT}_{1}$ in Scheme 3). This PCET process can occur either in stepwise or concerted fashion, and it results in $\left[\mathrm{Ru}^{\mathrm{III}}(\mathrm{bpy})_{2} \mathrm{pyim}\right]^{2+}, \mathrm{MQ}^{\bullet}$, and HOAc (PCET arrow in Scheme 3). Subsequent proton transfer $\left(\mathrm{PT}_{2}\right.$ step in Scheme 3) between buffer acid (HOAc) and MQ then leads to the photoproducts detected in Fig. $5 \mathrm{c}$. In fact, these two reaction steps can be temporally resolved (see below).

The reaction free energies for all conceivable reaction pathways are summarized in Scheme 4. The driving-forces in Scheme 4 emerge directly from the thermodynamic parameters of the two reaction partners in Schemes 1 and 2. The overall formal HAT process is dissected into photoexcitation (black arrows), electron transfer from the metal complex to monoquat (blue arrows), proton transfer from the metal complex to buffer base $\left(\mathrm{PT}_{1}\right.$, red arrows), and proton transfer from buffer acid to monoquat $\left(\mathrm{PT}_{2}\right.$, red arrows) as discussed above on the basis of Scheme 3.

From the starting point at the top left corner of Scheme 4, concerted proton-electron transfer (CPET) to form $\left[\mathrm{Ru}^{\mathrm{III}}(\mathrm{bpy})_{2} \mathrm{pyim}\right]^{2+}$, $\mathrm{MQ}^{\bullet}$, and protonated buffer base (HOAc) is a plausible initial 


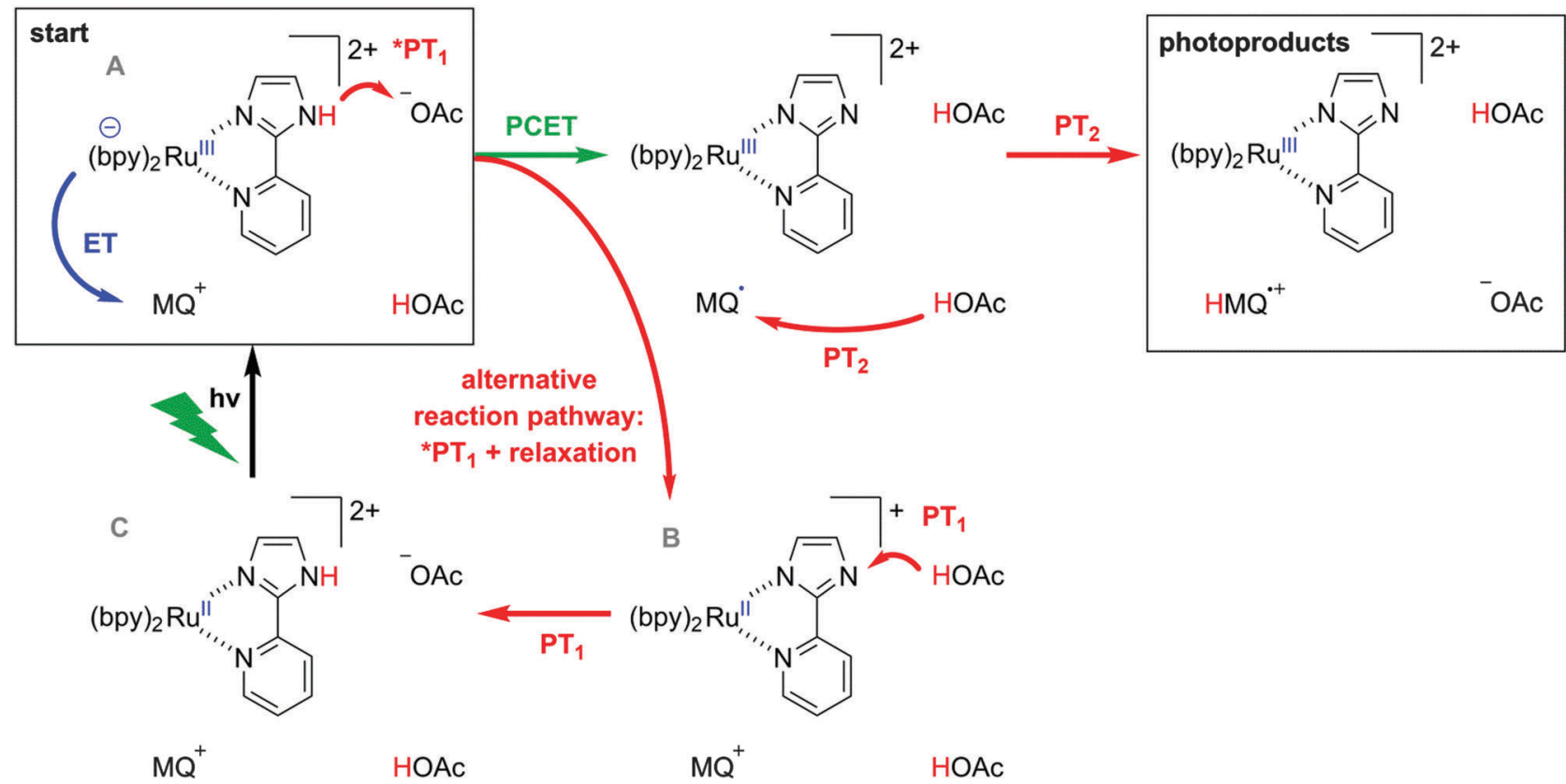

Scheme 3 Possible pathways for reaction of * $\left[\mathrm{Ru}(\mathrm{bpy})_{2} \mathrm{pyimH}\right]^{2+}$ with $\mathrm{MQ}^{+}$in acetate-buffered solution.

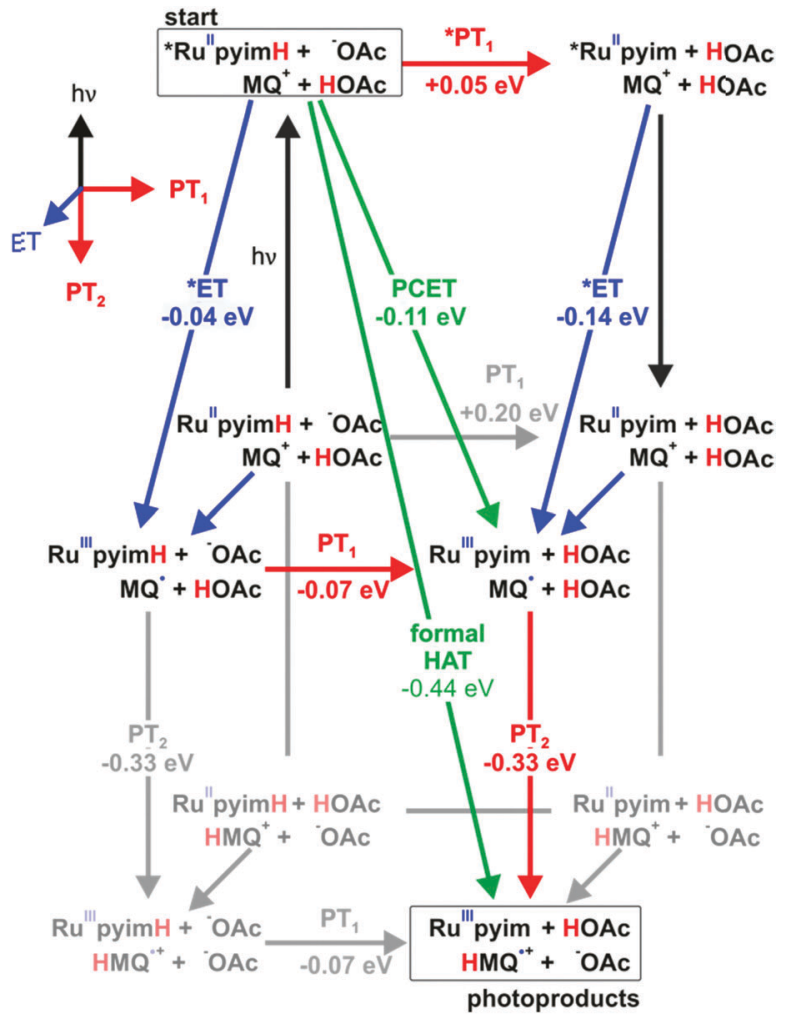

Scheme 4 Extended "cube"-scheme illustrating all reaction pathways for formal HAT between ${ }^{*}\left[\mathrm{Ru}(\mathrm{bpy})_{2} \text { pyimH }\right]^{2+}$ and $\mathrm{MQ}^{+}$in acetate-buffered solution (based on a combination of Schemes 1 and 2). Excited state chemistry is shown in the upper level, ET processes are pointing towards the reader, $\mathrm{PT}_{1}$ (complex to buffer base) is shown in horizontal direction and $\mathrm{PT}_{2}$ (buffer acid to monoquat) is shown in the two lower levels. Driving forces for the individual reaction steps are based on experimentally determined redox potentials and acidity constants. reaction pathway since $\Delta G_{\mathrm{PCET}}=-(0.11 \pm 0.16) \mathrm{eV}$ for this process (green arrow). However, a sequence of electron and proton transfer events cannot be excluded on thermodynamic grounds and would be equally compatible with our experimental data.

Classical Stern-Volmer luminescence quenching experiments could not be performed for determination of the kinetics of the initial PCET process (green arrow in Scheme 3) because the luminescence of $\left[\mathrm{Ru}(\mathrm{bpy})_{2} \text { pyimH }\right]^{2+}$ is strongly quenched in presence of buffer molecules $\left(k_{\mathrm{q}}=(8.3 \pm 0.5) \times 10^{8} \mathrm{~L} \mathrm{~mol}^{-1} \mathrm{~s}^{-1}\right.$ as described earlier). Therefore, we performed experiments at $5 \mathrm{mM}$ buffer concentration for which we used a different spectroscopic observable to monitor the kinetics of the relevant PCET process: when measuring the transient absorption spectrum immediately after laser excitation, an additional band at $500 \mathrm{~nm}$ becomes observable. Based on the data in Fig. $4 \mathrm{c}$ and d, this band can be attributed unambiguously to $\left[\mathrm{Ru}^{\mathrm{II}}(\mathrm{bpy})_{2} \text { pyim }\right]^{+}$, i.e., to the deprotonated $\mathrm{Ru}^{\mathrm{II}}$ complex in the electronic ground state. This species accumulates in a side-reaction to PCET as illustrated in the lower line, right side of Scheme 3; a subset of all excited complexes undergoes PCET chemistry to the photoproducts shown in the top right corner of Scheme 3 whereas another subsets merely acts as a photoacid (lower line, right side). Thus, the intensity of the transient absorption signal at $500 \mathrm{~nm}$ is a measure for the amount of ruthenium complexes that have been photoexcited but that have not undergone PCET chemistry. The temporal evolution of the transient signal at $500 \mathrm{~nm}$ shows classical A $\rightarrow \mathrm{B} \rightarrow \mathrm{C}$ reaction kinetics (Fig. 6a), with species A corresponding to ${ }^{*}\left[\mathrm{Ru}^{\mathrm{II}}(\mathrm{bpy})_{2} \text { pyimH }\right]^{2+}$, species B being $\left[\mathrm{Ru}^{\mathrm{II}}(\mathrm{bpy})_{2} \mathrm{pyim}\right]^{+}$, and species $\mathrm{C}$ corresponding to the protonated ground state as shown in Scheme 3. In absence of $\mathrm{MQ}^{+}$the signal at $500 \mathrm{~nm}$ rises with $\tau^{\mathrm{A} \rightarrow \mathrm{B}}=(105 \pm 10) \mathrm{ns}$ and decays with $\tau^{\mathrm{B} \rightarrow \mathrm{C}}=(1.0 \pm 0.1) \mu \mathrm{s}$. With increasing $\mathrm{MQ}^{+}$ concentration $\tau^{\mathrm{A} \rightarrow \mathrm{B}}$ decreased, $\tau^{\mathrm{B} \rightarrow \mathrm{C}}$ remained constant and 

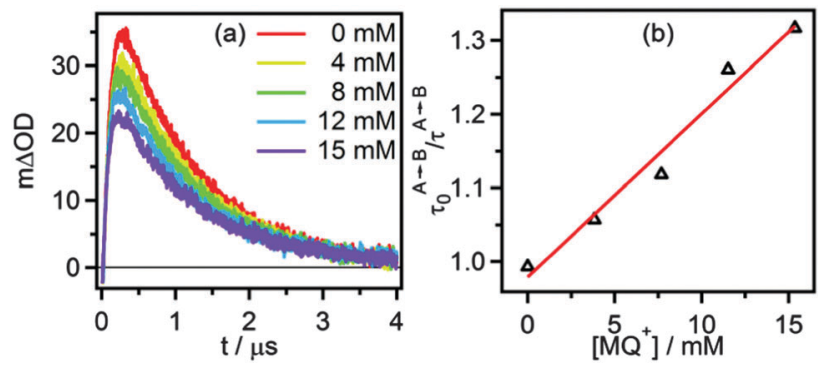

Fig. 6 (a) Change in optical density at $500 \mathrm{~nm}$ as a function of time after $532 \mathrm{~nm}$ excitation of $40 \mu \mathrm{M}\left[\mathrm{Ru}(\mathrm{bpy})_{2} \text { pyimH }\right]^{2+}$ in $1: 1(\mathrm{v}: \mathrm{v}) \mathrm{CH}_{3} \mathrm{CN} / \mathrm{H}_{2} \mathrm{O}$ containing $5 \mathrm{mM}$ acetate buffer and increasing concentrations of $\mathrm{MQ}^{+}$. (b) Pseudo Stern-Volmer plot based on the kinetics for step A $\rightarrow$ B with constant $B \rightarrow C$ lifetime, see text for details.

the maximum intensity of the signal decreased. A plot of $\tau_{0}^{\mathrm{A} \rightarrow \mathrm{B}} / \tau^{\mathrm{A} \rightarrow \mathrm{B}} v s$. $\left[\mathrm{MQ}^{+}\right]$is shown in Fig. $6 \mathrm{~b}$. A linear regression fit yields a pseudo-Stern-Volmer constant $\left(K_{\mathrm{SV}}{ }^{\prime}\right)$ of $(22 \pm 2) \mathrm{L} \mathrm{mol}^{-1}$ and a quenching constant $\left(k_{\mathrm{q}}{ }^{\prime}\right)$ of $(2.1 \pm 0.4) \times 10^{8} \mathrm{~L} \mathrm{~mol}^{-1} \mathrm{~s}^{-1}$. This PCET-quenching constant is on the same order of magnitude as the ${ }^{*} \mathrm{PT}_{1}$-quenching constant and therefore both processes are competitive.

In buffered solution at $\mathrm{pH} 6.3$ the final PCET photoproducts (i.e. $\left[\mathrm{Ru}^{\mathrm{III}}(\mathrm{bpy})_{2} \mathrm{pyim}\right]^{2+}$ and $\mathrm{HMQ}^{\bullet+}$ ) are formed within the first microsecond at buffer concentrations between 5 and $50 \mathrm{mM}$ (Fig. 5c). When monitoring the transient absorption signals at $387 \mathrm{~nm}$ and $610 \mathrm{~nm}$ (Fig. 7b and c) it becomes evident that the formation of $\mathrm{HMQ}^{\bullet+}$ occurs more slowly than deactivation of the ${ }^{3}$ MLCT excited state of the $\left[\mathrm{Ru}^{\mathrm{II}}(\mathrm{bpy})_{2} \mathrm{pyimH}\right]^{2+}$ complex (Fig. 7a). Based on the emission decay at $630 \mathrm{~nm}$, the ${ }^{3}$ MLCT

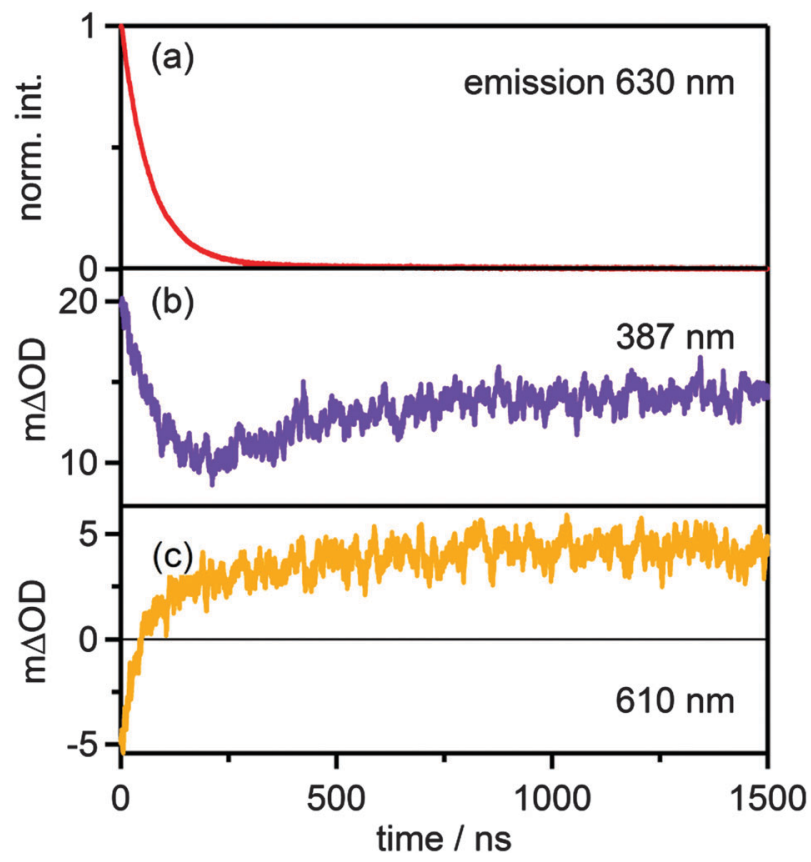

Fig. 7 (a) Decay of the emission signal at $630 \mathrm{~nm}$ and temporal evolution of the transient absorption signal at $387 \mathrm{~nm}$ (b) and at $610 \mathrm{~nm}$ (c) in the reaction of $40 \mu \mathrm{M}\left[\mathrm{Ru}(\mathrm{bpy})_{2}\right.$ pyimH] ${ }^{2+}$ with $15 \mathrm{mM} \mathrm{MQ}^{+}$in $1: 1$ (v:v) $\mathrm{CH}_{3} \mathrm{CN} / \mathrm{H}_{2} \mathrm{O}$ at $\mathrm{pH} 6.3$ with $5 \mathrm{mM}$ acetate buffer.
Table 3 Stern-Volmer constants $\left(K_{\mathrm{SV}}\right)$ and bimolecular luminescence quenching constants $\left(k_{\mathrm{q}}\right)$ for ${ }^{*}\left[\mathrm{Ru}(\mathrm{bpy})_{2} \text { pyimH }\right]^{2+}$ in presence of $\mathrm{MQ}^{+}$in deaerated 1:1 (v:v) $\mathrm{CH}_{3} \mathrm{CN} / \mathrm{H}_{2} \mathrm{O}$ at different $\mathrm{pH}$ values in absence and presence of buffer

\begin{tabular}{lccl}
\hline Conditions & $K_{\mathrm{SV}}\left[\mathrm{L} \mathrm{mol}^{-1}\right]$ & $k_{\mathrm{q}}\left[10^{8} \mathrm{~L} \mathrm{~mol}^{-1} \mathrm{~s}^{-1}\right]$ & Process \\
\hline Buffered pH 2 & $143 \pm 13$ & $6.8 \pm 0.1$ & ET \\
Unbuffered pH 13 & $124 \pm 12$ & $20.7 \pm 0.3$ & ET \\
Buffered pH 6.3 & $34 \pm 2$ & $5.7 \pm 0.3$ & PCET \\
Unbuffered $\mathrm{H}_{2} \mathrm{O}$ pH 7.3 & $70 \pm 5$ & $3.4 \pm 0.5$ & PCET \\
Unbuffered $\mathrm{D}_{2} \mathrm{O}$ pD 7.3 & $58 \pm 6$ & $2.5 \pm 0.8$ & PCET
\end{tabular}

lifetime under these conditions is $(70 \pm 7) \mathrm{ns}$. Biexponential fits to the transients at $387 \mathrm{~nm}$ and $610 \mathrm{~nm}$ yield time constants of $(70 \pm 7) \mathrm{ns}$ and $(250 \pm 25) \mathrm{ns}$ with different signs of amplitude, corresponding to the ${ }^{3}$ MLCT lifetime and the time constant for formation of $\mathrm{HMQ}^{\bullet+}$, respectively. Thus, photoexcited $\left[\mathrm{Ru}^{\mathrm{II}}(\mathrm{bpy})_{2} \text { pyimH }\right]^{2+}$ disappears more rapidly than $\mathrm{HMQ}^{\bullet+}$ forms, and this can be explained by rapid PCET (green arrow in Scheme 3) followed by slow $\mathrm{PT}_{2}$ (red arrow in Scheme 3). By increasing the buffer concentration the kinetics of these processes is accelerated as described in the ESI $\dagger$ (Fig. S12).

In absence of buffer the reaction kinetics are different. The absence of buffer base leaves $\mathrm{MQ}^{+}$and water molecules as potential proton acceptors. The luminescence quenching experiment performed with acetate buffer (Fig. S7, ESI $\dagger$ ) clearly shows that buffer base is a far better proton acceptor than water vis-àvis photoexcited $\left[\mathrm{Ru}^{\mathrm{II}}(\mathrm{bpy})_{2} \text { pyimH }\right]^{2+}$. Transient absorption spectra recorded in $1: 1(\mathrm{v}: \mathrm{v}) \mathrm{CH}_{3} \mathrm{CN} / \mathrm{H}_{2} \mathrm{O}$ in absence of buffer are shown in Fig. 5d. The spectrum recorded without time delay (orange trace in Fig. 5d) is compatible with the formation of neutral $\mathrm{MQ}^{\bullet}$ radical as a primary photoproduct, exhibiting a characteristic broad absorption centered on $545 \mathrm{~nm}$. After $5 \mu$ s the population of $\mathrm{MQ}^{\bullet}$ has decreased and $\mathrm{HMQ}^{\bullet+}$ can be detected (brown trace in Fig. 5d). Thus, the overall photochemistry is the same as in presence of buffer (PCET followed by $\mathrm{PT}_{2}$ ), but the kinetics are much different. The time constant for protonation of $\mathrm{MQ}^{\bullet}$ is $(2.5 \pm 0.3) \mu$ s based on the temporal evolution of the transient signal at $610 \mathrm{~nm}$ (ESI, $\dagger$ Fig. S13a) which is a factor of 10 slower than in the presence of $5 \mathrm{mM}$ acetate buffer. Stern-Volmer luminescence quenching studies yielded $k_{\mathrm{q}}=(3.4 \pm 0.5) \times 10^{8} \mathrm{~L} \mathrm{~mol}^{-1} \mathrm{~s}^{-1}$ for the initial excitedstate quenching process. When going from $\mathrm{CH}_{3} \mathrm{CN} / \mathrm{H}_{2} \mathrm{O}$ to $\mathrm{CH}_{3} \mathrm{CN} / \mathrm{D}_{2} \mathrm{O}$, the protonation of $\mathrm{MQ}^{\bullet}\left(\mathrm{PT}_{2}\right)$ is slowed down by a factor of 2.6, and the initial excited state quenching process becomes a factor of $(1.4 \pm 0.6)$ slower (Table 3$)$. In principle, an $\mathrm{H} / \mathrm{D}$ kinetic isotope effect of 1.4 would be compatible with concerted electron-proton transfer (CPET), but definitive assignment of the PCET step in Scheme 3 (green arrow) either to concerted or consecutive electron and proton transfer steps is currently not possible.

\section{Summary and conclusion}

The thermodynamic properties of $\left[\mathrm{Ru}(\mathrm{bpy})_{2} \mathrm{pyimH}\right]^{2+}$ in its electronic ground state and in the long-lived ${ }^{3}$ MLCT excited state in $1: 1(\mathrm{v}: \mathrm{v}) \mathrm{CH}_{3} \mathrm{CN} / \mathrm{H}_{2} \mathrm{O}$ were explored in detail. In the 
ground state the formal $\mathrm{BDFE}$ of the $\mathrm{N}-\mathrm{H}$ bond is in the range of primary and secondary amines $\left((91 \pm 1) \mathrm{kcal} \mathrm{mol}^{-1}\right),{ }^{2,47,48}$ but upon excitation with a visible photon the BDFE drops by roughly $50 \mathrm{kcal} \mathrm{mol}^{-1}$ to only $(43 \pm 5) \mathrm{kcal} \mathrm{mol}^{-1}$. Thus, photoexcitation leads to a formal $\mathrm{N}-\mathrm{H}$ BDFE in the range of metal hydride complexes which are used as hydrogenation catalysts in their electronic ground states. ${ }^{4,38}$ Transient absorption spectroscopy demonstrates that photoexcited $\left[\mathrm{Ru}(\mathrm{bpy})_{2} \text { pyimH }\right]^{2+}$ and ( $N$-methyl-4, $4^{\prime}$-bipyridinium, $\mathrm{MQ}^{+}$) undergo a formal HAT reaction, thereby confirming the finding of a very low formal $\mathrm{N}-\mathrm{H}$ BDFE in the ruthenium complex; in $\mathrm{HMQ}^{\bullet+}$ the $\mathrm{N}-\mathrm{H}$ BDFE is $(53 \pm 1) \mathrm{kcal} \mathrm{mol}^{-1}$. Mechanistically, formal HAT between these two reactants is found to proceed via a sequence of PCET and proton transfer reaction steps involving buffer or solvent molecules. More generally, our study demonstrates that aromatic imines can be reduced from the excited state of $\left[\mathrm{Ru}(\mathrm{bpy})_{2} \text { pyimH }\right]^{2+}$.

\section{Acknowledgements}

This work was supported by the Swiss National Science Foundation through grant number 200021_146231/1.

\section{Notes and references}

1 D. R. Weinberg, C. J. Gagliardi, J. F. Hull, C. F. Murphy, C. A. Kent, B. C. Westlake, A. Paul, D. H. Ess, D. Granville and T. J. Meyer, Chem. Rev., 2012, 112, 4016-4093.

2 J. J. Warren, T. A. Tronic and J. M. Mayer, Chem. Rev., 2010, 110, 6961-7001.

3 S. Hammes-Schiffer, J. Am. Chem. Soc., 2015, 137, 8860-8871.

4 M. Bourrez, R. Steinmetz, S. Ott, F. Gloaguen and L. Hammarström, Nat. Chem., 2015, 7, 140-145.

5 J. M. Mayer, D. A. Hrovat, J. L. Thomas and W. T. Borden, J. Am. Chem. Soc., 2002, 124, 11142-11147.

6 T. Irebo, S. Y. Reece, M. Sjödin, D. G. Nocera and L. Hammarström, J. Am. Chem. Soc., 2007, 129, 15462-15464.

7 T. Irebo, M.-T. Zhang, T. F. Markle, A. M. Scott and L. Hammarström, J. Am. Chem. Soc., 2012, 134, 16247-16254.

8 V. W. Manner, A. D. Lindsay, E. A. Mader, J. N. Harvey and J. M. Mayer, Chem. Sci., 2012, 3, 230.

9 A. Wu, J. Masland, R. D. Swartz, W. Kaminsky and J. M. Mayer, Inorg. Chem., 2007, 46, 11190-11201.

10 J. P. Roth, J. C. Yoder, T. Won and J. M. Mayer, Science, 2001, 294, 2524-2526.

11 J. P. Roth and J. M. Mayer, Inorg. Chem., 1999, 38, 2760-2761.

12 O. S. Wenger, Coord. Chem. Rev., 2015, 46, 150-158.

13 J. Nomrowski and O. S. Wenger, Inorg. Chem., 2015, 54, 3680-3687.

14 J. C. Freys, G. C. Bernardinelli and O. S. Wenger, Chem. Commun., 2008, 4267-4269.

15 T. T. Eisenhart and J. L. Dempsey, J. Am. Chem. Soc., 2014, 136, 12221-12224.

16 H. G. Yayla and R. Knowles, Synlett, 2014, 2819-2826.
17 K. T. Tarantino, P. Liu and R. R. Knowles, J. Am. Chem. Soc., 2013, 135, 10022-10025.

18 J. J. Concepcion, M. K. Brennaman, J. R. Deyton, N. V. Lebedeva, M. D. E. Forbes, J. M. Papanikolas and T. J. Meyer, J. Am. Chem. Soc., 2007, 129, 6968-6969.

19 N. V. Lebedeva, R. D. Schmidt, J. J. Concepcion, M. K. Brennaman, I. N. Stanton, M. J. Therien, T. J. Meyer and M. D. E. Forbes, J. Phys. Chem. A, 2011, 115, 3346-3356.

20 Y. Deng, J. A. Roberts, S.-M. Peng, C. K. Chang and D. G. Nocera, Angew. Chem., Int. Ed., 1997, 36, 2124-2127.

21 J. P. Kirby, J. A. Roberts and D. G. Nocera, J. Am. Chem. Soc., 1997, 119, 9230-9236.

22 J. Rosenthal, J. M. Hodgkiss, E. R. Young and D. G. Nocera, J. Am. Chem. Soc., 2006, 128, 10474-10483.

23 E. R. Young, J. Rosenthal, J. M. Hodgkiss and D. G. Nocera, J. Am. Chem. Soc., 2009, 131, 7678-7684.

24 C. Bronner and O. S. Wenger, J. Phys. Chem. Lett., 2012, 3, 70-74. 25 C. Bronner and O. S. Wenger, Inorg. Chem., 2012, 51, 8275-8283.

26 S. M. Barrett, C. L. Pitman, A. G. Walden and A. J. M. Miller, J. Am. Chem. Soc., 2014, 136, 14718-14721.

27 J. F. Ireland and P. A. H. Wyatt, Adv. Phys. Org. Chem., Elsevier, 1976, vol. 12, pp. 131-221.

28 C. R. Waidmann, A. J. M. Miller, C.-W. A. Ng, M. L. Scheuermann, T. R. Porter, T. A. Tronic and J. M. Mayer, Energy Environ. Sci., 2012, 5, 7771-7780.

29 M.-A. Haga, Inorg. Chim. Acta, 1983, 75, 29-35.

30 M.-A. Haga and A. Tsunemitsu, Inorg. Chim. Acta, 1989, 164, 137-142.

31 A. M. Bond and M. Haga, Inorg. Chem., 1986, 25, 4507-4514.

32 M. Haga, M. M. Ali, S. Koseki, K. Fujimoto, A. Yoshimura, K. Nozaki, T. Ohno, K. Nakajima and D. J. Stufkens, Inorg. Chem., 1996, 35, 3335-3347.

33 M.-A. Haga, Inorg. Chim. Acta, 1980, 45, L183-L184.

34 M. Haga, T. Ano, T. Ishizaki, K. Kano, K. Nozaki and T. Ohno, J. Chem. Soc., Dalton Trans., 1994, 263.

35 X. Xiaoming, M. Haga, T. Matsumura-Inoue, Y. Ru, A. W. Addison and K. Kano, J. Chem. Soc., Dalton Trans., 1993, 2477.

36 K. M. Lancaster, J. B. Gerken, A. C. Durrell, J. H. Palmer and H. B. Gray, Coord. Chem. Rev., 2010, 254, 1803-1811.

37 A. $\mathrm{Wu}$ and J. M. Mayer, J. Am. Chem. Soc., 2008, 130, 14745-14754.

38 J. Choi, M. E. Pulling, D. M. Smith and J. R. Norton, J. Am. Chem. Soc., 2008, 130, 4250-4252.

39 A. J. Morris, R. T. McGibbon and A. B. Bocarsly, ChemSusChem, 2011, 4, 191-196.

40 J. Chen, K. Wu, B. Rudshteyn, Y. Jia, W. Ding, Z.-X. Xie, V. S. Batista and T. Lian, J. Am. Chem. Soc., 2016, 138, 884-892.

41 D. J. Boston, C. Xu, D. W. Armstrong and F. M. MacDonnell, J. Am. Chem. Soc., 2013, 135, 16252-16255.

42 A. A. Vlcek, E. S. Dodsworth, W. J. Pietro and A. B. P. Lever, Inorg. Chem., 1995, 34, 1906-1913.

43 A. Yoshimura, M. Z. Hoffman and H. Sun, J. Photochem. Photobiol., A, 1993, 70, 29-33.

44 L. M. Tolbert and K. M. Solntsev, Acc. Chem. Res., 2002, 35, 19-27. 
45 J. W. Park, Y. Kim and J. M. Kim, Bull. Korean Chem. Soc., 1993, 174-175.

46 A. Harriman, G. R. Millward, P. Neta, M. C. Richoux and J. M. Thomas, J. Phys. Chem., 1988, 92, 1286-1290.

47 F. G. Bordwell, X. Zhang and J. P. Cheng, J. Org. Chem., 1991, 56, 3216-3219.

48 F. G. Bordwell, X. M. Zhang and J. P. Cheng, J. Org. Chem., 1993, 58, 6410-6416.

49 D. P. Rillema, R. Sahai, P. Matthews, A. K. Edwards, R. J. Shaver and L. Morgan, Inorg. Chem., 1990, 29, 167.
50 C. J. Gagliardi, B. C. Westlake, C. A. Kent, J. J. Paul, J. M. Papanikolas and T. J. Meyer, Coord. Chem. Rev., 2010, 254, 2459-2471.

51 P. S. Braterman and J. I. Song, J. Org. Chem., 1991, 56, 4678-4682.

52 D. M. Roundhill, Photochemistry and Photophysics of Metal Complexes, Springer US, Boston, MA, 1994.

53 A. Juris, V. Balzani, F. Barigelletti, S. Campagna, P. Belser and A. von Zelewsky, Coord. Chem. Rev., 1988, 84, 85-277. 